\title{
PRIMJENA TESTOVA IZDRŽLJIVOSTI U RADU SA STUDENTIMA FAKULTETA BEZBJEDNOSNIH NAUKA
}

\author{
Darko Paspalj $^{1}$ i Milan Gužvica ${ }^{1}$ \\ ${ }^{1}$ Fakultet bezbjednosnih nauka, Univerzitet u Banjoj Luci, Bosna i Hercegovina
}

Originalni naučni članak

\section{SA ŽETAK}

Istraživanje je provedeno na uzorku od 27 studenata prve godine Fakulteta bezbjednosnih nauka muškog pola sa ciljem utvrđivanja vrijednosti funkcionalnih sposobnosti studenata postignutih prilikom izvedbe Kuperovog testa $i$ Beep testa, radi razmatranja mogućnosti primjene Beep testa u procjeni funkcionalnih sposobnosti studenata prilikom provođenja procesa selekcije za prijem na školovanje. Odgovarajućom statističkom procedurom utvrđeno je da ne postoji statistički značajna povezanost varijabli za procjenu morfoloških karakteristika sa ostvarenim rezultatima na Beep testu i Kuper testu kao i da ne postoji statistički značajna povezanost varijabli za procjenu morfoloških karakteristika sa dobijenim rezultatima maksimalne potrošnje kiseonika na Beep testu i Kuper testu. Takođe je utvrđeno da ne postoji razlika u maksimalnoj potrošnji kiseonika između primijenjenih testova. Zbog varijabilnosti opterećenja koje je karakteristčno za Beep test $i$ sličnosti sa specifičnim aktivnostima karakterističnim za izvođenje elemenata i njihovih veza u procesu nastave iz SFO-a, autori predlažu uvrštavanje Beep testa u bateriju testova za provjeru funkcionalnih sposobnosti kandidata prilikom provođenje procesa selekcije kandidata za prijem na školovanje na Fakultetu bezbjednosnih nauka. Dobijene informacije takođe se mogu koristiti pri izradi i optimizaciji plana i programa SFO-a, kao i pri stvaranju homogenih grupa s ciljem efikasnosti usvajanja nastavne građe.

Ključne riječi: studenti, kuperov test, beep test, selekcija

\section{UVOD}

Pod nastavom u Specijalnom fizičkom obrazovanju (u daljem tekstu SFO), podrazumijeva se proces planskog i sistematskog prenošenja i usvajanja specijalnih tematskih područja prilagođenih studentima Fakulteta bezbjednosnih nauka, relevantnih za buduće obavljanje profesionalnih dužnosti i obaveza, u kom su zastupljene mnoge komponente, od kojih su osnovne: sticanje znanja, formiranje umijenja, formiranje navika i utvrđivanje znanj i navika. Izvođenje i praktična primjena tehnika iz programa SFO-a uslovljena je, kako visokim tehničkim i motoričkim sposobnostima, tako i funkcionalnim i mentalnim sposobnostima, ali i odgovarajućim antropometrijskim predispozicijama. Za realizaciju nastavnog procesa i aktivno učešće polaznika u nastavi SFO-a pored motoričkih sposobnosti snage, brzine, gipkosti, koordinacije, agilnosti, preciznosti i ravnoteže, veoma važnu ulogu ima i izdržljivost. Pod izdržljivosti se podrazumijeva sposobnost pojedinca da održi svoju radnu sposobnost kroz duže vreme zbog čega je potrebno da svaki pojedinac ima razvijen optimalan nivo funkcionalnih sposobnosti, pri čemu dominiraju mješoviti aerobno-anaerobni energetski procesi koje karakterišu jednostavna i složena kretanja. Pelemiš, Mitrović, Cicović i Lolić (2011) navode da fiziološku osnovu fizičkog radnog kapaciteta čini funkcionalna sposobnost organizma da poveća nivo metaboličkih procesa u skladu za zahtjevima fizičkog napora kojem se izlaže, pri čemu pod metaboličkim procesima podrazumijevaju transformaciju hemijske energije u mišićnu kontrakciju. Prema Miloševiću nivo razvoja funkcionalnih karakteristika uslovljava brzinu razvoja sile, brzinu kretanja i dugotrajno vršenje rada bez vidljivih znakova umora i bez većeg smanjenja njegove efikasnosti a zavisi od energetskih rezervi i funkcionalnog kvaliteta energetskog niza koji osigurava snabdijevanje mišića energijom za rad iz adenozintrifosfata. (Milošević, M., i Milošević, M. 2013). Vučić (2016), u svom diplomskom radu, 
navodi da aerobna sposobnost predstavlja sposobnost organizma da aerobnim metaboličkim procesima (oksidativnom razgradnjom ugljenih hidrata i slobodnih masnih kiselina) stvara energiju potrebnu za fizički rad i vezuje se za aktivnosti u kojima se sva potrebna energija za mišićni rad obezbjeđuje iz oksidativnih metaboličkih procesa. Veličina aerobne sposobnosti zavisi od funkcionalnog stanja svih organskih i metaboličkih sistema koji učestvuju u transportu kiseonika i korištenju istog za stvaranje potrebne energije za rad. Kao osnovni fiziološki pokazatelj aerobnih funkcionalnih sposobnosti organizma koriste se vrijednosti maksimalne potrošnje kiseonika ( $\left.\mathrm{V}_{2} \max \right)$, što podrazumijeva najveću količinu kiseonika koju organizam može potrošiti u jednoj minuti (Matković i Ružičić 2009), a izražavaju se u apsolutnim (1/min) ili relativnim jedinicama (ml/kg/min). Skinner i McLellan, (1980) navode da kod aerobnog praga potrošnja kiseonika postiže stabilnu vrijednost koja odgovara intenzitetu rada od umjerene fizičke aktivnosti, kojom prilikom dolazi do povećanja koncentracije mliječne kiseline u radnom mišiću i krvi iznad nivoa u mirovanju, pri čemu je još uvijek moguća ravnoteža između akumulacije i razgradnje laktata, te postizanja stabilnog stanja potrošnje kiseonika i stabilne koncentracije mliječne kiseline u krvi.

Ograničeni broj časova koji je predviđen za učenje i usavršavanje predviđenog programa iz SFO-a, zahtijeva stalno traganje za novim sredstvima i metodama, pa samim tim i veće prisustvo nauke i njenu implementaciju kako u procesu učenja, tako i procesu usavršavanja studenata. Program SFO-a karakterišu polistrukturalna aciklična kretanja, što ga čini veoma kompleksnim i energetski veoma zahtjevnim, jer je za njihovo izvođenje potrebno često korištenje fosfagenih izvora energije. Program predviđa potpunu kontrolu agresivnosti i pokreta u statičkim i dinamičkim uslovima koji se ogledaju u dostignutim nivoima izvođenja tehnika, kao što su: kretanja, udarci, blokovi, poluge, čišćenja i bacanja, i to u što kraćem vremenu. Iako se većina programskih sadržaja SFO-a odvija u anaerobnim uslovima (pokreti i kretanja se izvode u najkraćoj vremenskoj jedinici), ne smije se zaboraviti ni mogućnost izvođenja i takvih motornih programa koji zahtijevaju znatno više vremena, pa samim tim i druge uslove (aerobnoanaerobne) u kojima će se motorni programi i realizovati. Ovo, naravno, podrazumijeva aktivnost u uslovima povećane potrošnje kiseonika i zavisi od energetskog kapaciteta organizma, koji treba da obezbijedi dovoljan broj ponavljanja specifičnih motornih programa. Visoki nivo energetskih kapaciteta daje mogućnost, ne samo za dugotrajniji rad i usvajanje specifičnih motornih programa iz SFO-a, već i mogućnost njihove praktične primjene. To znači da je za efikasnost realizacije potreban visoki intenzitet koji može potrajati i nekoliko minuta. Ovo je posebno vidljivo $u$ novonastalim $i$ nepredviđenim situacijama, gdje je neophodno reprogramiranje ranije formiranog motoričkog programa, koji zahtjevaju pojačane mentalne i tjelesne aktivnosti. Zato budući radnik bezbjednosnih poslova u vršenju svoje profesionalne dužnosti, mora da dostigne visok nivo fizičke, tehničke, taktičke, psihološke i integralne pripremljenosti. Naravno, ovo je veoma težak i kompleksan zadatak za koji je potrebno odgovarajuće vrijeme u kojem je moguć optimalan broj ponavljanja jednostavnih i složenih situacija. Nažalost, optimalan broj ponavljanja u raspoloživom vremenu za obuku, koji bi omogućio automotizaciju elemenata tehnike i njihovih veza, jednostavno nije moguć. Vjeruje se da bi i u ograničenom vremenu predviđenom za obuku, visoki nivo specifične izdržljivosti studentima omogućio veći broj ponavljanja, što bi znatno uticalo na usvajanje datih motoričkih programa. Visoki nivo svih aspekata fizioloških sposobnosti, kao i visoki nivo tehničkospecifičnih sposobnosti, omogućio bi budućim radnicima bezbjednosnih poslova uspješnu primjenu programa iz SFO-a. Blagojević, Dopsaj i Vučković (2006) na osnovu dosadašnjih istraživanja navode da je za efikasno vršenje standardnog policijskog posla potrebno da aerobne sposobnosti policijskih službenika budu razvijene na nivou maksimalne potrošnje kiseonika između 48 i $50 \mathrm{ml} / \mathrm{kg} / \mathrm{min}$. Isti autori (2016) navode da policajci sa većim nivoom opšte izdržljivosti tj. sa većim nivoom razvijenosti aerobnog energetskog sistema statistički značajnije lakše kompenzuju stresogenu situaciju i da se u situacijama specifičnog zamora brže oporavljaju od stresa. Evidentno je da za uspješno obavljanje bezbjednosnih poslova fizičke sposobnosti pojedinaca moraju biti na odgovarajućem nivou, i to je jedan od razloga zašto im se pri selekciji 
kandidata za upis na školovanje poklanja sve veća pažnja. S obzirom na to da su studenti Fakulteta bezbjednosnih nauka (FBN) prilikom upisa na školovanje podvrgnuti provjeri motoričkih i funkcionalnih sposobnosti, može se reći da nakon odabira kandidata spadaju u homogenu grupu, zbog čega je ideja za istraživanje proizašla upravo iz potrebe da se ispita uticaj morfoloških karakteristika u procjeni funkcionalnih sposobnosti i vrijednosti maksimalne potrošnje kiseonika $\left(\mathrm{VO}_{2} \max \right)$. Iako je poznato da je „stvarnu“ maksimalnu potrošnju kiseonika najbolje procijeniti u laboratoriji, ipak, zbog visoke cijene i nepraktičnosti organizacije, autori su se odlučili za procjenu funkcionalnih sposobnosti u terenskim uslovima. Procjena aerobnih sposobnosti vršena je na osnovu rezultata maksimalne potrošnje kiseonika ostvarene na Kuperovom i Beep testu maksimalnog višestepenog opterećenja povratnim trčanjem na 20 metara, što ujedno i predstavlja predmet ovog istraživanja. Prilikom selekcije kandidata za upis na Fakultet bezbjednosnih nauka, kod procjene funkcionalnih, metaboličkih procesa, predviđen je Kuper test koji podrazumijeva kontinuiranost, već njegovom vremenskom određenošću, dok se Beep test maksimalnog višestepenog opterećenja povratnim trčanjem na 20 metara odlikuje diskontinuitetom, tj. akceleracijom i deceleracijom kretanja, što karakteriše i izvođenje motoričkih programa iz SFOa.

Istraživanje je provedeno sa ciljem da se utvrdi mogućnost predikcije vrijednosti funkcionalnih sposobnosti postignutih prilikom izvedbe Kuperovog testa na osnovu vrijednosti funkcionalnih sposobnosti postignutih prilikom izvedbe Beep testa, radi razmatranja mogućnosti primjene Beep testa maksimalnog višestepenog opterećenja povratnim trčanjem na 20 metara u selekciji kandidata i procjeni funkcionalnih sposobnosti prilikom provođenja procesa selekcije za prijem na školovanje.

\section{METODE}

Istraživanje je provedeno tokom sedam dana, $\mathrm{u}$ toku kojih je izvršeno prikupljanje $\mathrm{i}$ klasifikovanje podataka, te njihova statistička obrada. Uzorak ispitanika činilo je 27 studenata prve godine Fakulteta bezbjednosnih nauka iz Banjaluke muškog pola, starosti $19 \pm 0,6$ godina, klinički zdravih bez vidljivih tjelesnih nedostataka ili morfoloških aberacija. Osnovni antropomorfološki pokazatelji testiranog uzorka su bili: TV 183,11 $\pm 5,12 \mathrm{~cm}, \mathrm{TM}$ 81,25 $\pm 8,02$ kg i ITM 22,35 $\pm 1,96$. Kako bi se utvrdila polazna osnova za selekciju kandidata i realizaciju nastave polaznika, a da bi se dobili podaci o njihovim bazičnim morfološkim predispozicijama, bilo je potrebno utvrditi da li se na osnovu somatskog statusa može vršiti predikcija rezultata na testovima funkcionalnih sposobnosti kako bi se izbjegao bilo kakav vid diskriminacije kandidata i polaznika. Za utvrđivanje morfoloških karakteristika analizirane su varijable: tjelesna masa (TM), tjelesna visina (TV) i index tjelesne mase (ITM). Ove varijable su odabrane jer su pokazatelji postojanja poremećaja $u$ ishrani koji dovode do pojave pretilosti ili pothranjenosti što može da se odrazi na motoričke sposobnosti i izvedbu testova. Morfološke karakteristike su utvrđene dan prije izvedbe prvog testa pomoću antropometra po Martinu (tjelesna visina) i Body compozition analyser marke Tanita model BC-418 (tjelesna masa i ITM). Varijable, kojima je kod ispitanika indirektnom metodom utvrđen nivo funkcionalnih sposobnosti ispitanika su bili testovi za procjenu nivoa izdržljivosti: Kuper test i Beep test maksimalnog višestepenog opterećenja povratnim trčanjem na 20 metara (čiji su autori Leger \& Lambert 1982), kao dva terenska testa za procjenu funkcionalnih sposobnosti koja su najčešće korištena u dosadašnjoj praksi. Oba testa su provedena po standardnoj proceduri na atletskoj stazi u intervalu od sedam dana, pri čemu je prvi dan korišten Kuperov test, a nakon pet dana, tokom kojih su ispitanici bili oslobođeni obaveznih fizičkih aktivnosti, i Beep test. Procjena maksimalne potrošnje kiseonika za Kuper test određena je na osnovu formule za procjenu maksimalne potrošnje kiseonika (koju je dao Sudarov 2007. godine), a koja glasi: $\mathrm{VO}_{2} \max (\mathrm{ml} / \mathrm{kg} / \mathrm{min})=($ Pretrčana udaljenost $(\mathrm{m})-$ 504.9) / 44.73. Procjena maksimalne potrošnje kiseonika primjenom Beep testa određena je uvrštavanjem pretrčanog nivoa Beep testa u ,beep calculator“, a koja je, opet, izračunata na osnovu algoritma (Legel i Gadoury, 1989), pri čemu je: VO2max $(\mathrm{ml} / \mathrm{kg} / \mathrm{min})=18.043461+$ $(0.3689295 \times$ TS $)+(-0.000349$ x TS x TS $)$, gdje TS označava ukupan broj intervala. Statistička obrada podataka urađena je na PC računaru Pentijum 4, uz upotrebu aplikacionog statističkog 
programa SPSS (verzija 20,00). Osnovne mjere centralne tendencije i mjere disperzije rezultata definisane su pomoću: aritmetičke sredine (Mean) i standardne devijacije (Std. Deviation). U cilju testiranja pravilnosti distribucije podataka korišten je Kolmogorov-Smirnov test, dok je za utvrđivanje povezanosti varijabli morfoloških karakteristika i rezultata korištena korelaciona analiza, a za predikciju rezultata postignutih u testovima na osnovu morfoloških karakteristika primijenjena je regresiona analiza. Povezanost rezultata između rezultata Beep testa i Kuper testa utvrđena je korelacionom analizom.

\section{REZULTATI}

Tabela 1. Deskriptivna statistika Beep testa i varijabli za procjenu morfoloških karakteristika

\begin{tabular}{ccccccc}
\hline Varijable & N & Min & Max & Mean & S D & KS test \\
\hline AVIT & 27 & 170,00 & 193,00 & 183,11 & 5,12 & 0,856 \\
ATET & 27 & 60,00 & 89,00 & 81,25 & 8,02 & 0,992 \\
ITM & 27 & 18,87 & 26,26 & 22,35 & 1,96 & 0,999 \\
VO2 BEEP & 27 & 36,40 & 53,70 & 44,37 & 4,48 & 0,849 \\
BEEP & 27 & 980 & 2040 & 1453,33 & 276,68 & 0,903 \\
\hline
\end{tabular}

Legenda: N - broj ispitanika; Min. - minimalan rezultat; Max. - maksimalan rezultat; Mean - aritmetička sredina; Std. Deviation - standardna devijacija; KS (p) - vrijednost vjerovatnoće Kolmogorov- Smirnov testa; AVIT tjelesna visina, ATET - tjelesna težina, ITM - indeks tjelesne mase, $\mathrm{VO}_{2}$ BEEP - maksimalna potrošnja kiseonika ostvarena na Beep testu; BEEP - broj pretrčanih metara ostvarenih na Beep testu.

U Tabeli 1. prikazane su deskriptivne vrijednosti varijabli za procjenu morfoloških karakteristika i varijabli za procjenu maksimalne potrošnje kiseonika i rezultata broja pretrčanih metara ostvarenih na Beep testu. Pokazalo se da je distribucija rezultata dobro grupisana i da nema značajnijih odstupanja od srednjih vrijednosti rezultata što pokazuje i vrijednost KS testa. Prilikom analize razlika između minimalnog i maksimalnog rezultata, najveću vrijednost ranga pokazala je varijabla Beep test (BEEP), a najmanju vrijednost ranga maksimalna potrošnja kiseonika na Beep testu $\left(\mathrm{VO}_{2} \mathrm{~B}\right)$. Kod Beep testa ispitanici su ostvarili najveći rezultat od 2.040 metara i najmanji od 980 metara, uz raspon između minimalnog i maksimalnog rezultata od 1.060 metara. Analizom maksimalne potrošnje kiseonika kod Beep testa vidljivo da su ispitanici ostvarili maksimalnu vrijednost rezultata od $53,70(\mathrm{ml} / \mathrm{kg} / \mathrm{min})$ i minimalanu od 36,40 ( $\mathrm{ml} / \mathrm{kg} / \mathrm{min})$, uz raspon od 17,3 ( $\mathrm{ml} / \mathrm{kg} / \mathrm{min})$.

Tabela 2. Regresiona analiza $\mathrm{VO}_{2} \max$ Beep testa $\mathrm{i}$ varijabli za procjenu morfoloških karakteristika

\begin{tabular}{lcccc}
\hline Model & $\mathrm{R}$ & $\mathrm{R}^{2}$ & Prilagođen $\mathrm{R}^{2}$ & Std. greška \\
\hline 1 &, $231^{\mathrm{a}}$ &, 053 &,- 070 & 4,64143 \\
\hline
\end{tabular}

a. Prediktori (konstante) AVIT, ATET, ITM

b. Zavisna varijabla $\mathrm{VO}_{2} \mathrm{BEEP}$ 
Tabela 3. Rezultati $\mathrm{VO}_{2} \max$ na Beep testu na osnovu morfoloških karakteristika

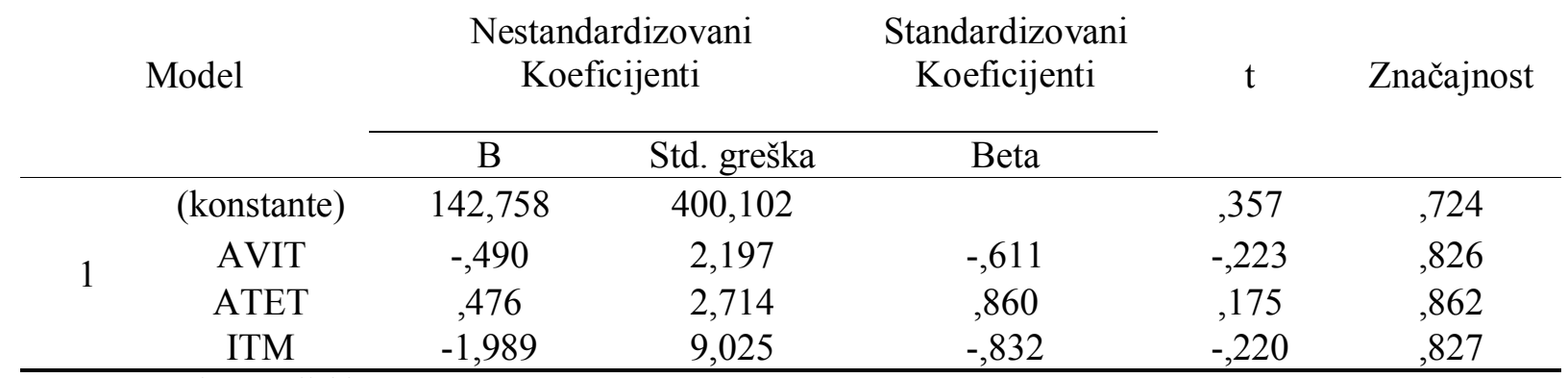

a. Zavisna varijabla: $\mathrm{VO}_{2} \mathrm{BEEP}$

$\mathrm{Na}$ osnovu regresione analize (Tabela 2) može se primijetiti da povezanost mjera morfologije sa rezultatom maksimalne potrošnje kiseonika postignutima na Beep testu $\left(\mathrm{VO}_{2}\right.$ $\max$ ) iznosi $r=0,231$ ili $23 \%$, dok je ostalih $77 \%$ neobjašnjeno ili pod uticajem drugih faktora. Kad je analizirana predikcija rezultata maksimalne potrošnje kiseonika na Beep testu na osnovu varijabli za procjenu morfoloških karakteristika (Tabela 3), može se ustanoviti da nije utvrđena statistički značajna predikcija rezultata maksimalne potrošnje kiseonika na Beep testu na osnovu primijenjenih varijabli za procjenu morfoloških karakteristika .

Tabela 4. Regresiona analiza Beep testa i varijabli za procjenu morfoloških karakteristika

\begin{tabular}{lcccc}
\hline Model & $\mathrm{R}$ & $\mathrm{R}^{2}$ & Prilagođen $\mathrm{R}^{2}$ & Std. greška \\
\hline 1 &, $225^{\mathrm{a}}$ &, 051 &,- 073 & 286,636 \\
\hline
\end{tabular}

a. $\quad$ Prediktori (konstante) AVIT, ATET, ITM

b. Zavisna varijabla BEEP

Tabela 5. Rezultati Beep testa (pređeni metri) na osnovu morfoloških karakteristika

\begin{tabular}{|c|c|c|c|c|c|c|}
\hline & \multirow[t]{2}{*}{ Model } & \multicolumn{2}{|c|}{$\begin{array}{l}\text { Nestandardizovani } \\
\text { Koeficijenti }\end{array}$} & \multirow{2}{*}{$\begin{array}{c}\begin{array}{c}\text { Standardizovani } \\
\text { Koeficijenti }\end{array} \\
\text { Beta }\end{array}$} & \multirow[t]{2}{*}{$\mathrm{t}$} & \multirow[t]{2}{*}{ Značajnost } \\
\hline & & $\mathrm{B}$ & Std. greška & & & \\
\hline \multirow{4}{*}{1} & (konstante) & 7849,050 & 24708,714 & & ,318 & ,754 \\
\hline & AVIT & $-32,127$ & 135,673 &,- 650 &,- 237 & 815 \\
\hline & ATET & 31,783 & 167,615 & ,931 &, 190 & 851 \\
\hline & ITM & $-129,790$ & 557,367 &,- 880 &,- 233 & 818 \\
\hline
\end{tabular}

a. Zavisna varijabla: BEEP

Analizom rezultata regresione analize (Tabele 4 i 5) može se primijetiti da povezanost morfoloških karakteristika sa rezultatom postignutima na Beep testu (pređeni metri) iznosi $\mathrm{r}=$ 0,225 ili $22,5 \%$, dok je ostalih 77,5\% ostalo neobjašnjeno ili je pod uticajem nekih drugih faktora. Kad je analizirana predikcija rezultata Beep testa (pređeni metri) na osnovu varijabli za procjenu morfoloških karakteristika, nije utvrđena statistički značajna predikcija rezultata Beep testa (pređeni metri) na osnovu primijenjenih varijabli za procjenu morfoloških karakteristika. 
Tabela 6. Korelacija prediktorskih varijabli sa rezultatima Beep testa $\left(\mathrm{VO}_{2}\right.$ max i pređeni metri)

\begin{tabular}{ccccc}
\hline \multirow{2}{*}{ BEEP } & AVIT & ATET & ITM \\
\cline { 3 - 5 } & Pearsonova korelacija &,- 150 &,- 220 &,- 179 \\
& Značajnost (dvostrana) &, 456 &, 271 &, 371 \\
$\mathrm{VO}_{2}$ BEEP & Pearsonova korelacija &,- 151 &,- 226 &,- 187 \\
\cline { 2 - 5 } & Značajnost (dvostrana) &, 451 &, 256 &, 351 \\
& $\mathrm{~N}$ & 27 & 27 & 27 \\
\hline
\end{tabular}

$\mathrm{BEEP}$ - beep test, $\mathrm{VO}_{2} \mathrm{BEEP}$ - maksimalna potrošnja kiseonika na beep testu

Na osnovu rezultata korelacione analize (Tabela 6) može se primijetiti da ne postoji statistički značajna povezanost varijabli za procjenu morfoloških karakteristika sa rezultatom postignutima na Beep testu i maksimalnom potrošnjom kiseonika ostvarenom na Beep testu.

Tabela 7. Deskriptivna statistika Kuperovog testa i varijabli za procjenu morfoloških karakteristika

\begin{tabular}{ccccccc}
\hline & N & Min & Max & Mean & S D & KS test \\
\hline AVIT & 27 & 170,00 & 193,00 & 183,11 & 5,12 & 0,856 \\
ATET & 27 & 60,00 & 89,00 & 81,25 & 8,02 & 0,992 \\
ITM & 27 & 18,87 & 26,26 & 22,59 & 1,96 & 0,999 \\
KUPER & 27 & 2550 & 3100 & 2761,85 & 152,59 & 0,582 \\
VO2 KUPER & 27 & 45,40 & 57,60 & 50,10 & 3,38 & 0,563 \\
\hline
\end{tabular}

Legenda: N - broj ispitanika; Min. - minimalan rezultat; Max. - maksimalan rezultat; Mean - aritmetička sredina; Std. Deviation - standardna devijacija; KS (p) - vrijednost vjerovatnoće Kolmogorov- Smirnov testa; AVIT tjelesna visina, ATET - tjelesna težina, ITM - indeks tjelesne mase, $\mathrm{VO}_{2} \mathrm{KUPER} \mathrm{-} \mathrm{maksimalna} \mathrm{potrošnja} \mathrm{kiseonika}$ ostvarena na Kuperovom testu; KUPER - broj pretrčanih metara ostvarenih na Kuperovom testu.

U Tabeli 7. prikazane su deskriptivne vrijednosti varijabli za procjenu morfoloških karakteristika i varijabli za procjenu maksimalne potrošnje kiseonika i rezultata broja pretrčanih metara ostvarenih na Kuper testu. Pokazalo se da je većina distribucija rezultata prilično dobro grupisana i da nema značajnijih odstupanja od srednjih vrijednosti rezultata. Normalitet rasporeda rezultata za primijenjene varijable testiran je pomoću Kolmogorov-Smirnov testa, pri čemu je vidljivo da su dobijene vrijednosti znatno iznad 0,00 što sugeriše da se prihvati hipoteza o normalnoj raspodjeli rezultata. Analizom rezultata Kuper testa vidi se da su ispitanici ostvarili najveći rezultat od 3.100 metara i najmanji od 2.550 metara, uz raspon između minimalnog i maksimalnog rezultata od 550 metara. Analizom maksimalne potrošnje kiseonika kod Kuper testa vidi se da su ispitanici ostvarili maksimalnu vrijednosti rezultata od $57,60(\mathrm{ml} / \mathrm{kg} / \mathrm{min})$ i minimalanu od 45,40 (ml/kg/min) uz raspon od 12,2 (ml/kg/min).

Tabela 8. Regresiona analiza maksimalne potrošnje kiseonika na Kuperovom testu i varijabli za procjenu morfoloških karakteristika

\begin{tabular}{lcccc}
\hline Model & $\mathrm{R}$ & $\mathrm{R}^{2}$ & Prilagođen $\mathrm{R}^{2}$ & Std. greška \\
\hline 1 & $288^{\mathrm{a}}$ &, 083 &,- 037 & 3,44911 \\
\hline
\end{tabular}

a. Prediktori (konstante) AVIT, ATET, ITM

b. Zavisna varijabla $\mathrm{VO}_{2} \mathrm{KUPER}$ 
Tabela 9. Rezultati maksimalne potrošnje kiseonika na Kuperovom testu na osnovu varijabli za procjenu morfoloških karakteristika

\begin{tabular}{|c|c|c|c|c|c|c|}
\hline \multirow[t]{2}{*}{ Model } & & \multicolumn{2}{|c|}{$\begin{array}{l}\text { Nestandardizovani } \\
\text { Koeficijenti }\end{array}$} & \multirow{2}{*}{$\begin{array}{c}\begin{array}{c}\text { Standardizovani } \\
\text { Koeficijenti }\end{array} \\
\text { Beta }\end{array}$} & \multirow[t]{2}{*}{$\mathrm{t}$} & \multirow[t]{2}{*}{ Značajnost } \\
\hline & & $\mathrm{B}$ & Std. greška & & & \\
\hline \multirow{4}{*}{1} & (konstante) & $-331,758$ & 297,321 & & $-1,116$ & ,276 \\
\hline & AVIT & 2,124 & 1,633 & 3,512 & 1,301 & ,206 \\
\hline & ATET & $-2,635$ & 2,017 & $-6,308$ & $-1,306$ & 204 \\
\hline & ITM & 8,532 & 6,707 & 4,725 & 1,272 &, 216 \\
\hline
\end{tabular}

a. Zavisna varijabla: $\mathrm{VO}_{2} \mathrm{KUPER}$

$\mathrm{Na}$ osnovu rezultata regresione analize (Tabela 8) može se primijetiti da povezanost varijabli za procjenu morfoloških karakteristika sa rezultatom maksimalne potrošnje kiseonika ostvarenim na kuperovom testu iznosi $r=0,288$ ili $28,8 \%$, dok je ostalih $71,2 \%$ neobjašnjeno ili pod je pod uticajem nekih drugih faktora. Kad je analizirana predikcija rezultata maksimalne potrošnje kiseonika na Kuperovom testu na osnovu varijabli za procjenu morfoloških karakteristika (Tabela 9), može se ustanoviti da nije utvrđena statistički značajna predikcija rezultata maksimalne potrošnje kiseonika na Kuperovom testu na osnovu primijenjenih varijabli za procjenu morfoloških karakteristika .

Tabela 10. Regresiona analiza Kuperovog testa i varijabli za procjenu morfoloških karakteristika

\begin{tabular}{lcccc} 
Model & $\mathrm{R}$ & $\mathrm{R}^{2}$ & Prilagođen $\mathrm{R}^{2}$ & Std. greška \\
\hline 1 &, $289^{\mathrm{a}}$ &, 084 &,- 036 & 155,294 \\
\hline
\end{tabular}

a. Prediktori (konstante) AVIT, ATET, ITM

b. Zavisna varijabla KUPER

Tabela 11. Rezultati Kuperovog testa (pređeni metri) na osnovu varijabli za procjenu morfoloških karakteristika

\begin{tabular}{|c|c|c|c|c|c|c|}
\hline \multirow[t]{2}{*}{ Model } & & \multicolumn{2}{|c|}{$\begin{array}{l}\text { Nestandardizovani } \\
\text { Koeficijenti }\end{array}$} & \multirow{2}{*}{$\begin{array}{c}\begin{array}{c}\text { Standardizovani } \\
\text { Koeficijenti }\end{array} \\
\text { Beta }\end{array}$} & \multirow[t]{2}{*}{$\mathrm{t}$} & \multirow[t]{2}{*}{ Značajnost } \\
\hline & & $\mathrm{B}$ & Std. greška & & & \\
\hline \multirow{4}{*}{1} & (konstante) & $-14570,704$ & 13386,688 & & $-1,088$ & ,288 \\
\hline & AVIT & 96,407 & 73,505 & 3,539 & 1,312 & 203 \\
\hline & ATET & $-119,541$ & 90,811 & $-6,352$ & $-1,316$ & 201 \\
\hline & ITM & 387,066 & 301,970 & 4,758 & 1,282 & ,213 \\
\hline
\end{tabular}

a. Zavisna varijabla: KUPER

Analizom rezultata regresione analize (Tabela 10) može se primijetiti da povezanost varijabli za procjenu morfoloških karakteristika sa rezultatom postignutima na Kuperovom testu (pređeni metri) iznosi $r=0,289$ ili 28,9\%, dok je ostalih 71,1\% neobjašnjeno ili pod uticajem nekih drugih faktora. Kada je analizirana predikcija rezultata Kuperovog testa (Tabela 11) na 
osnovu varijabli za procjenu morfoloških karakteristika, može se ustanoviti da nije utvrđena statistički značajna predikcija rezultata Kuperovog testa na osnovu primijenjenih varijabli za procjenu morfoloških karakteristika .

Tabela 12. Korelacija varijabli za procjenu morfoloških karakteristika i rezultata Kuperovog testa

\begin{tabular}{lcccc}
\hline \multirow{2}{*}{ KUPER } & & AVIT & ATET & ITM \\
\cline { 3 - 5 } & Pearsonova korelacija &,- 017 &,- 114 &,- 122 \\
& Značajnost (dvostrana) &, 933 &, 573 &, 546 \\
$\mathrm{~N}$ & 27 & 27 & 27 \\
\cline { 2 - 5 } $\mathrm{VO}_{2}$ KUPER & Pearsonova korelacija &,- 018 &,- 114 &,- 121 \\
& Značajnost (dvostrana) &, 927 &, 571 &, 548 \\
& $\mathrm{~N}$ & 27 & 27 & 27 \\
\hline
\end{tabular}

Analizom korelacije može se primIjetiti da ne postoji statistički značajna povezanost morfoloških karakteristika sa rezultatom postignutima na Kuperovom testu $\left(\mathrm{VO}_{2}\right.$ max i pređeni metri). U prilog ovome idu i prethodne analize koje su pokazale da pomenute karakteristike nemaju statistički značajnu povezanost sa rezultatima dobijenim na Beep testu i Kuper testu.

Tabela 13. Korelacija rezultata Kuperovog testa sa rezultatima Beep testa

\begin{tabular}{lccc}
\hline \multirow{2}{*}{ BEEP } & Pearsonova korelacija & KUPER & VO $_{2}$ KUPER \\
\cline { 3 - 4 } & Značajnost (dvostrana) &, 645 &, 736 \\
$\mathrm{~N}$ & 27 &, 000 \\
$\mathrm{VO}_{2} \mathrm{BEEP}$ & Pearsonova korelacija &, 688 & 27 \\
& Značajnost (dvostrana) &, 000 &, 712 \\
& $\mathrm{~N}$ & 27 &, 000 \\
& & & 27 \\
\hline
\end{tabular}

Iz Tabele 13 vidlljivo je da je dobijena visoka korelacija između Beep testa i Kuper testa kao i maksimalne potrošnje kiseonika ostvarene na Beep testu i Kuper testa. Takođe je dobijena veoma visoka korelacija između Beep testa i maksimalne potrošnje kiseonika na Kuperovom testu kao i maksimalne potrošnje kiseonika ostvarene na Beep testu i maksimalne potrošnje kiseonika ostvarene na Kuper testu. Ovi rezultati ukazuju da je moguće umjesto jednog koristiti drugi test, zavisno od uslova testiranja i same potrebe testiranja.

\section{DISKUSIJA}

$\mathrm{Na}$ osnovu vrijednosti rezultata antropometrijskih karakteristika studenata prikazanih u Tabeli 1. može se ustanoviti da prosječna visina uzorka od $183,11 \mathrm{~cm}$ uz masu tijela od $81,25 \mathrm{~kg}$ oslikava normalni indeks tjelesne mase $(22,59)$ ispitanika. Vrijednosti centralnih i disperzionih parametara za procjenu ostvarenih rezultata na Beep testu i maksimalne potrošnje kiseonika prilikom izvođenja Beep testa pokazuju normalnu raspodjelu i odslikavaju trenutnu fizičku sposobnost ispitanika. Rezultati prikazani u Tabelama 2 i 3 pokazuju da ne postoji statistički značajna kvalitativna povezanost između prediktorskih i kriterijumske varijable, što rezultira nemogućnošću predikcije rezultata maksimalne potrošnje kiseonika kod Beep testa na osnovu 
primijenjenih varijabli za procjenu morfoloških karakteristika. Takođe, skoro identični rezultati su dobijeni i u Tabelama 4 i 5 kod ostvarenog rezultata na Beep testu i mogućnosti predikcije ostvarenih rezultata na osnovu varijabli za procjenu morfoloških karakteristika. Upoređivanjem srednje vrijednost rezultata ispitanika ostvarenih na Beep testu sa predviđenim srednjim vrijednostima rezultata australijskih policijskih službi koje koriste Beep test za provjeru funkcionalnih sposobnosti svojih službenika (South Australia Police 9,04, Air servis Australia 9,60, Royal air force 9,10, Western Australia Police 10,1, Britanska armija 10,2 i Rojal marinci $13,00)$, vidi se da su rezultati ispitanika ispod predviđenog prosjeka, što govori da njihove funkcionalne sposobnosti, predviđene za uspješno obavljanje službenih poslova i zadataka, nisu na zadovoljavajućem nivou, dok upoređivanjem srednje vrijednosti rezultata maksimalne potrošnje kiseonika naših studenata ostvarenih na Beep testu sa srednjim vrijednostima rezultata predviđenima za taj uzrast, vidi se da su ispitanici ostvarili prosječan rezultat, na osnovu čega se može zaključiti da su aerobno-anaerobne sposobnosti ispitanika na prosječnom nivou. U Tabeli 6. prikazani su rezultati korelacione analize ostvarenog rezultata i rezultata maksimalne potrošnje kiseonika na Beep testu sa varijablama za procjenu morfoloških karakteristika. Relativno nizak nivo korelacionih koeficijenata potvrđuje podudarnost rezultata regresione analize kriterijuma $\mathrm{u}$ aktuelnom prediktorskom prostoru. Vrijednosti Pirsonovog koeficijenta korelacije pokazuju da je najveća povezanost ostvarenog rezultata (slaba negativna povezanost) $\mathrm{i}$ rezultata maksimalne potrošnje kiseonika na Beep testu dobijena sa varijablom tjelesna težina, iz čega proizlazi da su ispitanici sa manjom tjelesnom težinom ostvarili bolje rezultate a samim tim i veću maksimalnu potrošnju kiseonika. Međutim, iako ovo istraživanje nije pokazalo da longitudinalna dimenzionalnost ima efekte na rezultate testova za procjenu maksimalne potrošnje kiseonika, neka ranija istraživanja su došla do određenih rezultata vezanih za ovu problematiku. Prema Jakovljević, Ljubojević, Karalić, Gerdijan i Vukić (2014), uticaj antropometrijskih karakteristika na kondicione parametre fudbalera istražili su (Wong, Chamari, Dellal i Wisloff, 2009), kojom prilikom su dokazali da postoji statistički značajna povezanost između tjelesne visine i rezultata na Beep testu $(p=0,26)$, kao i tjelesne visine i maksimalne potrošnje kiseonika na Beep testu $(p=0,35)$. Rezultati povezanosti varijabli za procjenu morfoloških karakteristika i rezultata ostvarenih na Kuperovom testu i rezultati povezanosti varijabli za procjenu morfoloških karakteristika sa maksimalnom potrošnjom kiseonika na Kuperovom testu prikazani su u Tabelama 7,8,9,10 i 11. Kao i kod prethodnih rezultata može se konstatovati da ne postoji statistički značajna povezanost između prediktorskih i kriterijumske varijable, što takođe rezultira nemogućnošću predikcije rezultata ostvarenih na Kuper testu i rezultata maksimalne potrošnje kiseonika kod Kuper testa. Objašnjenje dobijenih rezultata moguće je potražiti u činjenici da se radi o selekcionisanom uzorku ispitanika čije vrijednosti morfoloških karakteristika se kreću u okviru normalne raspodjele. Treba napomenuti da su Mitrović i saradnici (2015) proveli istraživanje u kojem je ispitivana relacija između stanja tjelesne uhranjenosti i nivoa aerobne utreniranosti kod pripadnika specijalnih jedinica policije. Autori su na uzorku od 72 ispitanika muškog pola prosječne starosti $34,2 \pm 5,2$ godina, prosječnog radnog staža od $12,5 \pm 4,9$ godina i prosječne vrijednosti indeksa tjelesne mase od $27,59 \mathrm{~kg} / \mathrm{m}^{2}$, ispitivali relaciju između indeksa tjelesne mase i maksimalnog trčanja na 3000 metara kao jedne od varijanti Kuperovog testa. Zaključak istraživanja je bio da i kod selektovanih i treniranih policajaca postoje statistički značajne razlike između stanja uhranjenosti i brzine trčanja $u$ aerobnom energetskom režimu naprezanja i to u obrnuto proporcionalnom smjeru. Ova veza je objašnjena na nivou od 33,4\% zajedničke varijanse iz čega proizlazi zaključak da veći nivo tjelesne uhranjenosti ukazuje na statistički značajni nivo aerobne performanse. Rezultati korelacione analize ostvarenog rezultata i rezultata maksimalne potrošnje kiseonika na Kuper testu sa varijablama za procjenu morfoloških karakteristika prikazani su u Tabeli 12. Na osnovu Pirsonovog koeficijenta korelacije dobijeni su skoro identični rezultati kao i u Tabeli 6. Ukoliko se uporede rezultati ispitanika sa vrijednostima koje su predviđene kriterijumom za isti dobni uzrast na Kuper testu, uočava se da je stanje pripremljenosti ispitanika dobro. Da bi se dobila potpunija slika o funkcionalnim sposobnostima ispitanika, potrebno je sagledati istraživanja 
navedenih sposobnosti koja su provedena na sličnom uzorku ispitanika. Porede li se srednje vrijednosti rezultata ispitanika ostvarenih na Kuper testu sa srednjim vrijednostima rezultata koje su ostvarili studenti jedanaeste generacije Kriminalističko-policijske akademije iz Beograda (Blagojević, Dopsaj i Vučković 2006), vidljivo je da su ispitanici postigli rezultate približne rezultatima studenata jedanaeste generacije Kriminalističko-policijske akademije iz Beograda. U Tabeli 13 prikazana je poveznost rezultata Beep testa i Kuper testa i povezanost rezultata Beep testa sa maksimalnom potrošnjom kiseonika na Kuper testu. Iz tabele je vidljivo da postoji veoma visoka povezanost rezultata Beep testa sa rezultatima Kuper testa i maksimalnom potrošnjom kiseonika na Kuper testu kao i da postoji veoma visoka poveznost između maksimalne potrošnje kiseonika na Beep testu sa rezultatima Kuper testa i maksimalne potrošnje kiseonika na Kuper testu.

Pri naporima koji duže traju nije osnovna determinanta samo maksimalna potrošnja kiseonika koju ispitanik može postići na testiranju, već je veoma značajno na kom se nivou može iskoristiti maksimalni aerobni kapacitet. Što je veći stepen treniranosti, veći je i postotak mogućeg iskorišćenja aerobnog kapaciteta, iz čega proizlazi da će sposobniji biti onaj ispitanik koji može na višem nivou vršiti potrošnju kiseonika. Kod Kuper testa motivacija igra izuzetno veliku ulogu i izuzetno je bitan faktor uspjeha. Jednostavno, ne može se zanemariti činjenica da je test relativno naporan i da dugo traje, pa se zato objektivni pokazatelji stanja mogu očekivati samo kod visoko motivisanih pojedinaca. Takođe treba napomenuti da je Kuperov test praktički jedino moguće izvoditi na atletskoj stazi jer na drugim ravnim izmjerenim prostorima ispitanici se nakon nekoliko minuta toliko raziđu da ispitivač nije u mogućnosti pratiti sve ispitanike i zabilježiti njihov rezultat nakon isteka vremenskog perioda od 12 minuta. Beep test je jedna od najpopularnijih test procedura koja se u današnje vrijeme koristi u procjeni aerobne izdržljivosti (Leger i Boucher, 1980; L. A. Leger i Lambert, 1982; Leger, Mercier, Gadoury, i Lambert, 1988). Zbog same činjenice da se test izvodi dirigovano pri čemu je tempo trčanja definisan zvučnim signalom koji dolazi sa CD-a, računala ili drugog audio-izlaza, na Beep testu je nemoguće postići krivi rezultat, zbog prenaglašenog intenziteta trčanja ili zbog podcjenjivanja vlastitih sposobnosti. Test se u pravilu izvodi u zatvorenom prostoru, ali može se izvoditi i na otvorenom prostoru. Međutim upravo ova karakteristika da se Beep test može izvoditi u zatvorenom prostoru, značajna je komparativna prednost $\mathrm{u}$ odnosu na druge testove aerobne izdržljivosti. Najveća prednost ovog testa je što se istovremeno može testirati veća grupa ispitanika u malom prostoru pri čemu iskustvo samog ispitanika nema nikakav uticaj $\mathrm{u}$ izvođenju testa dok minimalne promjene brzine trčanja omogućavaju ispitanicima da vrlo precizno procjene potrebni intenzitet rada. Iako se većina programskih sadržaja SFO-a odvija u anaerobnim uslovima (pokreti i kretanja se izvode u najkraćoj vremenskoj jedinici), ne smije se zaboraviti ni mogućnost izvođenja i takvih motornih programa koji zahtijevaju znatno više vremena, pa samim tim i druge uslove (aerobno-anaerobne) u kojima će se motorni programi i realizovati. Ovo, naravno, podrazumijeva aktivnost u uslovima povećane potrošnje kiseonika i umnogome zavisi od energetskog kapaciteta organizma, koji treba da obezbijedi dovoljan broj ponavljanja specifičnih motornih programa. Visoki nivo energetskih kapaciteta daje mogućnost, ne samo za dugotrajniji rad i usvajanje specifičnih motornih programa iz SFO-a, već i mogućnost njihove praktične primjene. Dakle, ukoliko se želi da studenti u potpunosti usvoje specifične motorne programe s mogućnošću njihove praktične primjene, potrebno je da u samom procesu učenja i usavršavanja oni imaju i odgovarajuće energetske sposobnosti, koje bi im omogućile kako optimalni intenzitet u radu, tako i optimalni broj ponavljanja. Dobijene informacije mogu se koristiti pri izradi i optimizaciji plana i programa SFO-a, pri stvaranju homogenih grupa u nastavi, koja bi obezbjedila ravnomjernost učenja i usavršavanja, te pri selekciji kandidata za upis na FBN. 


\section{ZAKLJUČAK}

Istraživanje je provedeno sa ciljem da se utvrdi uticaj morfoloških karakteristika na vrijednosti rezultata Beep testa i Kuper testa i maksimalne potrošnje kiseonika na Beep testu i Kuper testu, kako bi se potvrdio uticaj definisanih varijabli kao opravdanih u dijagnostičkim terenskim testovima, te da se sagleda stanje funkcionalnih sposobnosti studenata na osnovu vrijednosti Beep testa i Kuper testa, ali i maksimalna potrošnja kiseonika na Beep testu i Kuper testu. Nakon dobijenih rezultata i njihove obrade odgovarajućom statističkom procedurom utvrđeno je da ne postoji statistički značajna povezanost varijabli za procjenu morfoloških karakteristika sa ostvarenim rezultatima na Beep testu i Kuper testu, kao i da ne postoji statistički značajna povezanost varijabli za procjenu morfoloških karakteristika sa otvarenim rezultatima maksimalne potrošnje kiseonika na Beep testu i Kuper testu. Nadalje, utvrđeno je da ne postoji razlika u maksimalnoj potrošnji kiseonika između primijenjenih testova, što se može objasniti specifičnošću primijenjenih testova. Na osnovu dobijenih rezultata i zbog karakteristika Beep testa i Kuper testa, te zbog mogućnosti mjerenja u različitim uslovima, autori predlažu da se u procesu selekcije kandidata za prijem na školovanje na Fakultetu bezbjednosnih nauka, provjera funkcionalnih sposobnosti kandidata vrši Beep testom. Imajući u vidu navedeno javlja se potreba da se u nekom sličnom istraživanju, preciznijim mjerenjem, utvrdi koliko dugo i u kojem režimu rada svaki pojedinac može da bude efikasan, ne samo prilikom usvajanja nastavnih sadržaja, već i za programiranje i kontrolu trenažnih postupaka iz oblasti SFO-a.

\section{LITERATURA}

Beep test $\mathrm{VO}_{2} \max$ calculator. (20.01.2014.).Topend sport \& Science resource. Retrieved (20.01.2014) from http://www.topendsports. com/testing/beepcalc.htm

Blagojević, M., Vučković, G. \& Dopsaj, M. (2006). Specijalno fizičko obrazovanje 1 - osnovni nivo, Kriminalističko policijska akademija, Beograd, RS.

Blagojević, M., Vučković, G. \& Dopsaj, M. (2016). Specijalno fizičko obrazovanje 2 -usmjereni nivo, Kriminalističko policijska akademija, Beograd, RS.

Jakovljević V., Ljubojević A., Karalić T., Gerdijan N. \& Vukić Ž. (2014). Relacije morfoloških karakteristika i maksimalne potrošnje kiseonika učenika četvrtog razreda osnovne škole u odnosu na pol. Fizička kultura, 68(1), 63-74.

Léger L. \& Boucher R. (1980). An indirect continuous running multistage field test: the Université de Montréal track test. Can J Appl Sport Sci. 5(2), 77-84.

Leger, L.A. \& Lambert, J. (1982). A maximal multistage $20 \mathrm{~m}$ shuttle run test to predict VO2max, European Journal of Applied Physiology, 49, 1-5.

Leger, L., Mercier D, Gadoury C. \& Lambert J. (1988). The multistage 20 metre shuttle run test for aerobic fitness. J Sports Sci. Summer, 6(2), 93-101.

Leger, L. \& Gadoury, C. (1989). Validity of the 20m shuttle run test with 1 minute stages to predict VO2max in adults. Canadian Journal of Sport Science, 14(1), 21-26

Matković, B. \& Ružić, L. (2009). Energija za rad. U: B. Matković i L. Ružić (ur.), Fiziologija sporta $i$ vježbanja, (pp 37-51). Zagreb, RH: Odjel za izobrazbu trenera Društvenog veleučilišta u Zagrebu; Kineziološki fakultet Sveučilišta u Zagrebu.

Milošević, M. \& Milošević, M. (2013). Specijalno fizičko obrazovanje - Naučne osnove, Beograd, RS: CEDIP.

Naughton, L.M., Cooley, D., Kemey, V., \& Smith,S. (1996). A comparision of two diff erent shuttle run test for the estimation of VO2 max. The Journal of Sports Medicine and Physical Fitness, 36 (2), 85-89.

Pavlović, R., Savić, V. \& Tošić, J. (2012). Uticaj morfoloških, motoričkih i funkcionalnih parametara u procjeni fitness indexa i maksimalne potrošnje kiseonika. Sport i zdravlje VII, $30-37$. 
Pelemiš, V., Mitrović, N., Cicović, B. \& Lolić, D. (2011). Maksimalna potrošnja kiseonika kod različitih grupa sportista. Sportske nauke i zdravlje 1(1), 52 - 57.

Ramsbottom et al. (1988). A progressive shuttle run test to estimate maximal oxygen uptake. British Journal of Sports Medicine, 22, 141-145.

Skinner, J. S., \& McLellan, T. H. (1980). The transition from aerobic to anaerobic metabolism. Research Quarterly Exercise and Sport, 51, 234-248.

Sudarov, N. (2007). Testovi za procenu fizičkih performansi. Novi Sad, RS. Pokrajinski zavod za sport.

Vučič, J. (2016). Procena maksimalne potrošnje kiseonika pomoću gasnog analizatora i trake za trčanje kao mera aerobne sposobnosti sportiste. Diplomski rad. Prirodno matematički fakultet Univerziteta u Novom Sadu.

Wong, P.L., Chamari, K., Dellal, A., \& Wislőff , U. (2009). Relationship between anthropometric and physiological characteristics in youth soccer players. The Journal of Strength and Conditioning Research, 23(4), 1204-1210.

Primljeno: 06.05.2017.

Odobreno: 26.06.2017.

Korespodencija:

Doc. dr DarkoPaspalj

Fakultet bezbjednosnih nauka

Univerzitet u Banjoj Luci

Bulevar vojvode Živojina Mišića 10 a, 78000 Banja Luka

Bosna i Hercegovina

Tel:+387 51333603

+38765906325

dpaspalj@yahoo.com 